\title{
Informal Cities: Peruvian Migration, Textile Workshops and Urban Space in Argentina*
}

\author{
María José Magliano**, María Victoria Perissinotti****
}

\begin{abstract}
Based on the findings of a qualitative research, this article analyzes the articulation between textile workshops, one of the main contributors in Peruvian migrant's insertion in the labor market in Argentina; and the specific way of inhabiting urban spaces configured by this productive process. We argue that the textile workshop represents an interesting case to study the relationship between production, reproduction and space in a peripheral location marked by a high presence of migrants. In Argentina textile industry, turned into a «migration labor activity» during the last decades, has become a paradigm of labor informalization and instability. In this context, we show how informalization allows local brands to reduce costs and increase profits within a broader supply chain. We also highlight that this same process compels textile migrant workers to rely upon the economic potential of community resources, within a framework of specific forms of labor insertion of Peruvian migrants in the territory. Keywords: textile workshops, migration, informalization, Argentina
\end{abstract}

\section{Introduction}

The main aim of this article is to analyze the articulation between textile workshops; one of the main contributors in Peruvian migrant's

* Articolo proposto: 09/09/2016. Articolo accettato: 18/02/2017.

** National Scientific and Technological Research Council (CONICET) and Faculty of Philosophy and Humanities, National University of Cordoba, Argentina. E-mail: mariajosemagliano@gmail.com.

*** National Scientific and Technological Research Council (CONICET) and Faculty of Philosophy and Humanities, National University of Cordoba, Argentina. E-mail: vperissinotti@gmail.com.

Sociologia del lavoro, n. 146/2017. ISSN 0392-5048. ISSNe 1972-554X.

DOI: $10.3280 /$ SL2017-146006 
insertion in the labor market in Argentina; and the specific way of inhabiting urban spaces configured by this productive process. We argue that the textile economic sector - and particularly, the textile workshops which our study focuses on - represents an interesting case to study the relationship between production, reproduction and space in a peripheral location marked by a high presence of migrants. Moreover, that relationship invites us to think about the economic potential of community resources, within a framework of specific forms of labor insertion of Peruvian migrants in the territory.

As in the majority of Latin American countries, in Argentina, the textile industry has undergone changes since the implementation of neoliberal policies at the end of $20^{\text {th }}$ century. As different studies point out, the productive restructuring in the textile industry during the last decades, have impacted on the characteristics of this economic sector, transforming it into an informal labor activity with a high presence of migrant workers (Barattini, 2010; Benencia, 2009).

On the one hand, economic deregulation during that period caused a removal of legal control in employment practices (Barattini, 2010). On the other hand, industrial strategies - focused on lowering costs - aimed at outsourcing certain productive processes. It is precisely the last process what has been outsourced: the sewing of the garment. This is how larger firms are no longer directly involved in the manufacturing of clothes, but outsource it to smaller textile workshops, pursuing maximum flexibility of the workforce, in amounts and in accordance with the needs of production (Basualdo, Esponda and Morales, 2014; Castles, 2013). Outsourcing and lack of legal control transformed textile industry into a favorable environment for irregular conditions of employment, such as labor exploitation, health risk situations and poor working conditions (Barattini, 2010, p. 463). Thus, the disappearance of formal manufacturing jobs within this sector went hand in hand with the growth of informal employment (Auyero and Burbano de Lara, 2012, p. 535).

In this context, textile work in Argentina turned into an economic sector abandoned by the argentine population, who reject its limited possibilities of social mobility and its exploitation conditions; and, at the same time, it worked as a refuge for South American migrants. Hence, the textile industry, reconverted into a "migrant economic sector", is configured as a paradigm of labor informality and instability (Benencia, 2009; Basualdo, Esponda and Morales, 2014; Caggiano, 2014)1.

1. Studies conducted in Brazil also show how the productive restructuring in the textile industry during the last decades have impacted on the characteristics of this 
Literature on migrant labor trajectories in textile workshops in Argentina has grown in recent years. In general terms, those studies are mostly concentrated on: ways of labor insertion in the textile sector (Bastia, 2007; Gago, 2014; Magliano, 2016); conditions of exploitation and exclusion generally dealt with by migrant workers (Barattini, 2010; Benencia, 2009); health problems related to the ways in which this activity is developed in the cities (Goldberg, 2013); the link between migration, textile workshops and gender roles (Magliano, 2016); and migrant workers' responses to labor exploitation within garment workshops (Caggiano, 2014; Montero Bressán and Arcos, 2017).

An issue not yet analyzed in depth in this research field is the role of space as a key factor in the expansion of certain productive processes like informal textile workshops. The proliferation of informal and relegated urban neighborhoods is a spatial expression of the fragmentation of Argentinean cities which in turn reflects and reinforces growing levels of social inequality (Auyero and Burbano de Lara, 2012). In those neighborhoods, informalization is fed by lack of State regulation and by the delegation to the community as a strategy of labor and family reproduction.

Contemporary migration to Argentina has been characterized by a mobility of workforce that arrived especially from South American countries (Paraguay, Bolivia and Peru) ${ }^{2}$. Peruvian migration to Argentina, in particular, has increased during 1990s as a consequence of the economic and political crisis suffered in Peru at that historical moment. Data show that this has been an urban migration, from a Peruvian city to an Argentinean city, with a high proportion of young women who have headed the process of working in the paid domestic service in Argentinean cities (Cerrutti, 2005; Falcón Aybar and Bologna, 2013; Magliano, Perissinotti and Zenklusen, 2014; Rosas, 2010). Migrant's life stories indicate that, over the last years, migration dynamics has evidenced some changes: female migration turned into familiar migration in an attempt to occupy specific niches of the labor market. Thus, in addition to paid domestic service and construction, textile workshop has become one

economic sector, becoming an informal labor activity with a high presence of migrant workers (Coutinho, 2015; Silva, 1999).

2. According to the last National Population Census (2010), the foreign population in Argentina reached 1,8 million (4,5 per cent of the total population), of which a third arrived during the period 2002-2010. The main origin of the foreign population is: Paraguay (30,4 per cent) followed by Bolivia (19,1 per cent), Chile (10 per cent), Peru (8,7 per cent), Italy ( 8,1 per cent). In Cordoba, the main origin of the foreign population is Peru (24,6 per cent) followed by Bolivia (22,65 per cent), Italy (9,7 per cent), Paraguay ( 8 per cent) and Spain (6,4 per cent). 
of the main areas of labor insertion for this population, including women and men $^{3}$.

In order to arrive, have a place to live in and find a job, social networks have fulfilled an important role within Peruvian migrants (Rosas, 2010). In their access to the cities, even in peripheral urban areas, contemporary migrants in Argentina dispute certain power relationships by disobeying property rights (Harvey, 1993), while settling in public and unused lands that belong to the State. It is in these marginal and relegated areas, precisely, where particular productive processes, such as those involved in informal textile workshops, take place.

The article begins by exploring the connections between migration, informalization and labor in the contemporary cities. In a second section, we expose the methodological frame that allowed us to collect the empirical evidence upholding the research. The findings presented in this paper are mainly based on the ethnographic fieldwork we conducted between 2012 and 2015 in Sabattini, a peripheral neighborhood in the city of Córdoba, mainly composed of Peruvian migrants who have moved to the city during the last 15 years. On the basis of this premise, in the third section we present the main results observed, highlighting how those findings contribute to the thinking of productive processes among global cities (Sassen, 2007), which cannot be understood outside migration.

\section{Migration, space and textile workshops}

The many connections between migration and labor have received growing attention within migration studies. Research on the diverse alternatives of workforce restructuring recognizes that finding a job depends on the intersection of different social identifications, including class, gender, nationality, ethnicity and race (Browne and Misra, 2003; Castles, 2013). Furthermore, labor market segmentation scholars have argued that these social cleavages are used to create labor hierarchies (Caro et al., 2015; Castles, 2013; Piore, 1979; Portes and Blach, 1985; Riesco Sanz, 2003). From this viewpoint, labor segregation is not a new process; on the contrary, it has conditioned every stage of capitalist development. Nevertheless, labor market segmentation has been modified in the context of the new global social geography (Sassen, 2003). This new social geog-

3. In Peru, before migration, some migrants had also worked in textile workshops, especially in Gamarra, a textile district located in Lima; while others worked in informal activities in Peruvian cities, such as street trending and odd jobs. 
raphy, which expresses a particular phase of the relationship between capital and labor, has configured a nomadic, flexible and disposable worker (Castles, 2013).

In migration studies, labor market segmentation refers to the distinct labor insertion between migrants and natives based on social recognition, labor conditions, and wage expectations (Piore, 1979; Portes and Bach, 1985). This labor segmentation relegates migrants into distinct labor sectors, usually informal, precarious and unstable. Besides, this unequal position within labor market can also turn into an unequal position within urban space (spatial segregation), educational system and political sphere.

As far as textile workshops are concerned, research on this field has centered on thinking about the ethnicization of migrant workforce in destination countries in a context of major changes within the textile industry worldwide (Ceccagno, 2016). In Argentina, textile jobs have become a migrant labor insertion since the changes this activity suffered during the last decades. Thus, nationality became a cleavage which segments labor markets according to industry strategies aimed at outsourcing certain productive processes (Caro et al., 2015, p. 1607).

The existence and proliferation of textile workshops in specific Argentinean urban areas, only guaranteed through informalization, show how the new ways of poverty and urban marginality rest on certain labor niches (Gago, 2014; Sassen, 2007; Wacquant, 2016). It is the same informalization that allows the reproduction of labor as well as the delegation of costs to the community.

\section{Data and Methods}

As Sassen (2007) and Wacquant $(2003,2016)$ argue, there are certain social processes likely to be understood only by adopting qualitative methodology. Due to their informality - and, sometimes, their illegality - the practices and phenomena that are being dealt with in this paper - i.e., the constitution of textile workshops in peripheral neighborhoods - is a case in point. In Argentina, as in most Latin American countries, informal textile workshops do not usually manage to meet the legal requirements for authorization. That may be the reason why we were not able to access to these places but after several months of ethnographic fieldwork.

Following Wacquant, we understand ethnographic work as «social research based on the close-up, on-the-ground observation of people and institutions in real time and space, in which the investigator embeds herself near (or within) the phenomenon so as to detect how and why 
agents on the scene act, think and feel the way they do» (Wacquant, 2003, p. 5). The main purpose of this methodological frame consists of being able to relate the particular and localized processes that we observed in Sabattini to global tendencies concerning productive and urban transformations. We understand that anthropology allows this analytical shift, since, as Geertz (1994) already pointed out, we do not study villages, but study in villages.

According to this general approach, between 2012 and 2015 we conducted ethnographic work in Sabattini, a neighborhood located at the east periphery of Córdoba city (Argentina) and inhabited mostly by Peruvian migrants ${ }^{4}$. A local NGO that was working at Sabattini at that time acted like a gatekeeper and connected us to a group of different Peruvian families living there. After this, we used two main techniques: participant observation and in-depth interviews. Participant observation consisted of weekly visits to the families we had met in Sabattini. There, we participated in their daily routines, such as housekeeping and children caring. It was our involvement in those day-to-day activities what gave us the opportunity to access one of the most important spaces in the life of those families: the textile workshop. After several months of sharing their daily practices, families started to integrate us into their work routines. The complex world of textile workshops caused us concern. Thus, we kept visiting these families, mostly during working hours, and observing their routines. Finally, after visiting these migrants' houses for more than a year, and after building a close «rapport» (Hammersley and Atkinson, 2007), we conducted in-depth interviews with our nearest informants.

As a result of these methodological strategies, we obtained three semistructured interviews with three different workshop owners (two women and one man) and fifteen informal in-depth interviews with other actors, such us their employees and neighbors. The semi-structured interviews were conducted face-to-face and recorded with the permission of the participants. These interviews consisted of a series of questions about the functioning of the garment manufacturing workshop and the expectations related to it; the migration process of its owner and its arrival to the neighborhood. The informal interviews, also conducted face-to-face, were more open and migrants, both women and men, could talk freely about their interests. These last interviews occurred during our participant-observation activities and were inextricably linked to them. Finally, we collected over

4. In order to protect the people involved in the research, we have changed the name of our informants as well as the name of the neighborhood. 
forty field notes, all of which were written when we came back after a day of field-work. Each field note registered one day of work and entailed a list of the crucial aspects of it: places we visited; people we saw; situations we participated in; conversations we had; dialogues we heard.

\section{The space of informality, or how the reproduction of textile work- shop is possible}

\subsection{The neighborhood, the house and the workshop}

It is important to highlight that textile workshops in Argentina are built under the consolidation of peripheral and informal neighborhoods, since their emergence and reproduction are not likely to be understood without taking into consideration the characteristics of the spaces they occupy. Thus, in this section we analyze how these factors took place in the constitution of textile workshops in Sabattini, in order to explore how informalization of both labor market and urban spaces shape the relations observed $^{5}$.

The history of this peripheral neighborhood dates back to the year 2009, when a group of impoverished families - mostly, Peruvian migrants - settled in public lands to build their houses. What motivated their arrival to this area was the unmet need of a house: many of them were not able to afford their rent in downtown areas; others could not stay in the lodgings they were renting - principally because family life is difficult to cope with in those crowded spaces -; and others were eager to have a place of their own. In 2014 there were 700 people living in Sabattini. According to their national origin, 56,2 per cent were Peruvian; 34,6 per cent Argentinean (many of them were children whose parents are Peruvian), 3,1 per cent Bolivian and 2,7 per cent Paraguayan.

In Argentina, as in the rest of Latin American countries, it has become increasingly difficult for the middle and poor classes to access urbanized land throughout the formal housing market. This is due to several factors, such as the insufficient purchasing power this social sectors present and the implementation of public policies that hinder access to the land (Rebord et al., 2014, p. 2). Faced with these difficulties, impoverished people in Argentina have turned into public land «occupation» as

5. In our research, informalization implies to go further than the description of a particular economic sector to include the combination of different factors that have promoted specific livelihood strategies of migrant population in Argentinean cities. 
a strategy to gain access to housing. These lands are usually depressed zones of the urban environment: they are flooding and collapsing areas; they have no public services and they are often overcrowded (Guber, 2004, p. 13). In this context, people develop self-production strategies in order to build their houses. Exactly as it happened in Sabattini's building process, local States remain tolerant of these strategies, since they are incapable to resolve people's needs (Rebord et al., 2014, p. 3) ${ }^{6}$.

However, for migrant population, access to housing presents even more difficulties. For instance, we can highlight lack of documents and discrimination, all of which limit the options available to them (Cravino, 2008; Terrones Ribas, 2005; Vaccotti, 2014). So, with virtually no chances of meeting the requirements that the formal housing market imposes, migrants appeal to the range of options that their migration networks offer them, which are framed within urban informality. It is in this scenario, and because of the pressing need to find a place to live in, that a series of public lands, like the one that holds Sabattini, emerge for these families as a possibility to build their houses and their neighborhood (Magliano, Perissinotti and Zenklusen, 2014). Thus, as it happens in the main cities of Argentina, this process results in a «growing concentration and expansion» (Falcón and Bologna, 2013, p. 240) of migrant assembling in neighborhoods located in peripheral and degraded urban areas, associated with the precariousness that strongly influences their migration experiences.

In 2008, in Sabattini, a group of Argentinean neighbors demarcated and occupied some areas of the land behind the National Railway, claiming - informally - the property of the place. During 2009, they began to sell parcels of land at prices that, compared to those of the formal market, were affordable. Peruvian migrants, aware of that possibility through their relatives and acquaintances, started buying parcels of land there. However, this did not represent an actual ownership of the land, as it was actually State owned. The only way that they could remain on that land was by their permanent presence there, since they did not have any legal claim on it. Because of the same reason, Sabattini - as other similar places in Argentina - does not have water supply, garbage collection, street lighting, among other public services.

Even with those disadvantages, building a house of their own motivated Peruvian families to settle in Sabattini. After some time working as employees and living in rented rooms, the possibility of owning a house and a textile workshop emerged when they found a place like Sabattini,

6. In 2013, in the city of Cordoba there were 134 informal and relegated neighborhoods, similar to Sabattini, with an estimate of 21.300 families living in those urban areas (Techo, 2013, p. 90). 
considering that the workshop space always forms part of the family house. Consequently, the expectation of owning a workshop - expectation that has shaped the migration project itself, even knowing that they should previously work as employees - is linked to the possibility of becoming homeowners in those specific areas of the city.

Once the issue of owning a house is settled, our informants start acquiring sewing machines. This is not a simple process though, since the prices of the machines are considerably high compared to the salaries they earn. As employees, they do not have a fixed salary but earn according to the pieces of clothing they sew. In a good month, this means that they are able to collect 400 dollars. The machines, on the other hand, cost not less than 300 dollars each, even the simpler ones, while the most sophisticated reach 600 dollars. This is even in the informal market, where all of our informants bought used machines at a lower cost.

Within this scenario, being able to buy a machine took our informants more than three years of working as employees. Once they own their first machines, they start offering their work to larger factories that indirectly hire their work, this time hired not as employees but as owners of textile workshops.

Informal textile workshops in Sabattini operate with local firms that mainly sell their production in the same city. The orders usually come from agents of those local clothing brands that outsource the sewing process in order to lower their production costs and increase their profits. In this context, as Ceccagno (2015) explains for the case of Chinese working regimen in Italy, these firms managed to keep the cost down especially by working with these informal workshops run and staffed by migrants. As one of our interviewees told us: «I know they earn much more money than I do. Once I went to the mall and I saw the price at which they were selling a t-shirt I have sewn: 26 dollars. Do you know how much they paid me for that? 1,50 dollar» (Grace, Peruvian migrant, textile workshop owner, August 2015) ${ }^{7}$.

Most of the workshops set up in Sabattini have two to nine sewing machines. In those microbusinesses having only two machines, it is the married couple who does the work; those with a larger number of machines require other employees. Those employees are not usually family related, but it is the community network that allows the labor rela-

7. Informal textile workshops settled in other cities within Argentina, especially in Buenos Aires, show a similar structure and functioning as those of Sabattini. The researches of Bastia (2007), Benencia (2009), Dewey (2015), Gago (2014), Goldberg (2013), Montero Bressán and Arcos (2017), among others, analyses different dimensions of this labor activity in Buenos Aires. 
tionships, since all of them are Peruvian migrants who live in the same neighborhood. These networks also sustain the work agreements, since even the same idea of a work contract, a monthly salary or a time-table is inconceivable. On the contrary, the arrangements are settled periodically between the workshop owner and the employees for each new work they manage to obtain.

The neighborhood informal organization encourages and promotes the development of productive activities also maintained at the informal level. Besides textile workshops, the proliferation of small shops and food stands in Sabattini illustrates the ways in which migrants creatively benefit from informality.

In these deprived spaces, informality rests on the lack of State regulation, whose presence in the place is ambivalent. That ambivalence indicates that spaces such as Sabattini are not completely outside from the State practices and intervention. Thus, in this peripheral neighborhood, social and political organizations work as State agents regarding some of the population's requests. Considering some specific events, like a storm or a flood, State shows up by assisting the neighbors with sheets, mattresses, and food. In addition, people who reside in these relegated urban areas are receptors of focalized social programs and policies implemented to compensate for their vulnerability. One of the most important is the «Asignación Universal por Hijo», a monetary assistance introduced in Argentina in 2009. Through this policy every person, migrant or native, who is unemployed, working in the informal sector or earning less than the minimum wage, and having an Argentinean child under 18, receives a monthly allowance per each child. As the majority of the families in Sabattini have young children born in Argentina, they currently receive this benefit, which consists of 60 dollars per month.

As De Marinis (2011, p. 89) stresses, cases like Sabattini demonstrate the «economization» of State resources in peripheral urban spaces, which does not imply «retreat» or «disappearance». Precisely, that «economization» allows the existence and reproduction of textile workshops that do not meet the legal requirements. This situation enables an «active process of inclusion of migrant labor» (Mezzadra, 2012, p. 171) not through its illegalization, as it frequently happens in Europe and in the United States, but throughout its informalization. Migrants who live in Sabattini are legal in terms of their migration status, in a framework of a migration policy that, since 2004, has facilitated the regularization of migrant population ${ }^{8}$.

8. According to statistics, more than 90 per cent of the migrant population living in Sabattini has legalized their migration status: 70 per cent has the permanent residence and 20 per cent the temporary residence. 
As a result of this informalization - that goes beyond the productive activity to involve migrant livelihood strategies as a whole -, the textile workshop facilitates the reproduction of a certain kind of job: an informal one, characterized by instability, labor exploitation and poor working conditions. Deficiencies in working conditions are linked to space deficiencies. In the case of Sabattini, most textile workshops that we have observed were built inside family houses, in a space that usually coincides with the kitchen. They are usually small places, with poor or no ventilation, almost no natural light and dangerous electrical connections. There is a vital interdependence between productive and reproductive spaces in textile workshops, since «without domestic space, garment workers would not be able to develop their labor activity and, without that activity, they would not be able to even support the expenses of their precarious and unhealthy residences» (Gallinati, 2014, p. 93).

The particular kind of activity developed within textile workshops is also related to the ways in which the task is paid: piecework. This kind of agreement - common among textile workshops - consists of receiving certain amounts of money - usually an insignificant amount - per garment produced. Frequently, negotiations between the workshop owner and the local firms that buy their production barely reach two dollars the piece. Therefore, as one of our informants explained to us, «the only way of reaching an amount as closer to a salary is to sew as fast as you can, since the faster you finish with each garment, the faster you collect money» (Nancy, Peruvian migrant, textile workshop employee, October 2014).

Piecework results, consequently, in long working hours (10-12 hours per day), sometimes even all through the night. This is not only for the employees: the same owners of the workshops need to work as hard as them, since the profit margins are nearly inexistent. Furthermore, «the violent deregulation of capital-labor relations» that characterize the workshops we analyze result in the same owners needing to work as employees in other workshops, leading into an «extreme flexibility» of the workforce (Ceccagno, 2015, p. 1118).

Taking into consideration that all that is produced in Sabatini's textile workshops is destined to local brands, the production is traded outside the neighborhood, mostly downtown. It is then in the "center" of the cities the center in spatial and symbolic terms - where whatever is produced and manufactured in peripheral textile workshops gets consumed. 


\subsection{Community basis of textile workshops}

The close relationship between peripheral neighborhoods and informal textile workshops introduces the community dimension - understood as the «practical capacity of diverse human communities to cooperate between them» (Gutiérrez Aguilar, 2008, p. 35) - as an important element to recognize the complexity involved in this productive process. Community bonds and practices are connected to singular ways of living in those peripheral areas and, at the same time, are central to the production and maintenance of modes of intensive labor exploitation (Gago, 2014, p. 47). In our analysis, informalization reintroduces the category of community as a central resource that enables family and labor reproduction.

Thus, in the case of the textile workshops under analysis, we have found that community practices have territorial basis linked to peripheral neighborhoods and their constitution. Regarding Peruvian migrants, the community capital mobilized to the reproduction of daily life in Argentina does not have to do with a particular knowledge that "travels" along with them from their origin countries. Thereby, that capital is not related to an "ethnic" or "national" know-how; on the contrary, it is developed in a narrow relation to the migration processes and the strategies of accessing and living in urban spaces.

As we described previously, in order to manage the workshops, it is necessary to get employees ready to work under informal conditions and, simultaneously, to extend the network of contacts to obtain more clients that bring piecework. While clients and consumers reside outside the neighborhood, potential workers live in there, binding together the neighbors, also Peruvian, in a series of community practices. These practices, conceived as an «economy of reciprocity» (Gago, 2014, p. 47), seek to provide «knowledge and resources to improve living conditions in a historical time characterized by shortage and fragility of the established modes of social reproduction» (Quiroga Díaz and Gago, 2014, p. 11).

In Sabattini, one of the widespread community practices involves the free exchange of sewing machines among different textile workshops set up in the neighborhood. Thus, the support among migrants has allowed the expansion of textile workshops. The pandero constitutes another important community practice. This is an informal system of money lending adopted by a stable group of people, in this case Peruvian neighbors, who monthly contribute with a fixed amount of money to be distributed, in turns, among them. For example, in 2015 we registered over five pandero groups. The largest one was made by 10 families, while the smallest ones vary around five or six. The amount of money arranged was 
about 30 dollars per month. Every month there is a raffle and one person obtains the money collected; hence, at the end of the pandero cycle, everyone receives a corresponding amount of money. The significance of this practice, which is not specific to Peruvians in Argentina, lies on the fact that this money cannot be possibly earned by other means. As a Peruvian neighbor told us: «the most remarkable benefit of the pandero system is that money is received altogether»(Eliana, Peruvian migrant, February 2014).

This informal system of money lending can be defined as a community practice since it rests on trusting relationships among neighbors. Principally, it is because they live in the same space, and not because they are all Peruvians, that they trust each other. This money lending system becomes essential to the establishment and strengthening of textile workshops in those spaces, as it facilitates the purchase of those most expensive goods indispensable to the microbusiness ${ }^{9}$. As Mariano, an owner of a textile workshop in Sabattini, said to us: «if we had not participated in the pandero we had not been able to purchase the collareta sewing machine» (Mariano, Peruvian migrant, textile workshop owner, July 2015) ${ }^{10}$.

Community practices also work as a way of competition and dispute among neighbors based on the resources obtained from community mobilization but used subsequently by textile workshops for their own profit (Gago, 2014, p. 184). Electrical services, for example, gotten through neighbors' struggles, turn out as a free infrastructure for workshops owners, which emerge as an issue of continuing disagreement among neighbors, since they are blamed for power outage when large amounts of energy are used. This kind of dispute, related to a moral evaluation, derives from the discussion on how those - limited - resources, collectively conquered, should be consumed.

These practices, which respond to an informalization that goes through the daily life of impoverished migrant families who live in spaces like Sabattini, explain how the current restructuring of the labor market has delegated some of its function into the community (Sassen, 2007, p. 154). As part of an economic global system reproduced in a particular localization, the community dimension not only expresses new modes of social

9. The system is not exclusive for workshop owners. On the contrary, both owners and employees participate to it. For those migrants who do not have textile workshops but also participate in this money lending system; used cars, small motorcycles and electrical appliances are among the most valuable goods.

10. The collareta, one the most expensive sewing machines, enables to reinforce the piece of clothing. 
exploitation but also self-management capacities of people who live in the margins of the cities.

\section{Conclusion}

In this article, we have discussed how a productive process like textile manufacturing, which involves contemporary migrants in Argentina, finds its basis in particular ways of living in urban spaces. Indeed, our main argument was based on the fact that the construction of those peripheral neighborhoods was a precondition for the emergence of textile workshops. It is in these informal urban spaces where textile workshops cannot only appear, but also proliferate.

The places where these migrants dwell have some characteristics that play a central role in the constraints they deal with in their everyday lives. But, at the same time, present a series of opportunities for this population (Caro et al., 2015, p. 1604). Thus, spaces like Sabattini function not only as a factor of exclusion and segregation, since they are deprived and marginal areas, but also as a field of possibilities among that population searching for livelihood strategies.

The opportunity of having a textile workshop - even an informal and «clandestine» one - emerges only after and through the process of an «occupation» of public lands, within a context of increasing difficulties faced by migrant population to access and live in the cities. According to our analysis, informalization results an «established order», where the lack of State regulation and control allows some local brands to indirectly employ cheap labor to enlarge their profits. As Saitta (2015) argues, productive processes within contemporary capitalism are characterized by the existence of a continuum in the production cycles that combines both submerged (informal) and official (formal) production, making it impossible to distinguish between a formal and an informal product.

In a framework of an ambivalent presence of the State, what textile workshops located in Sabattini also reveal is that community resources become a useful alternative to manage the daily reproduction of migrant population who reside and work within those peripheral and informal urban areas. Those community resources are important in order to assure migrant livelihood, but also to maintain that particular and submerged way of production. As we have seen through the pages above, it is the articulation among production, reproduction and space what makes it possible to understand the emergence and proliferation of textile workshops like the ones we have observed in Sabattini. 


\section{References}

Auyero J., Burbano de Lara A. (2012). In harm's way at the urban margins. Ethnography, 13(4): 531-557. DOI: 10.1177/1466138111435746.

Barattini M. (2010). Trabajo esclavo y organización: el caso de la Unión de Trabajadores Costureros en Argentina. Estudios Demográficos y Urbanos, 25: 461-481.

Bastia T. (2007). From Mining to Garment Workshops: Bolivian Migrants in Buenos Aires. Journal of Ethnic and Migration Studies, 33(4): 655-669. DOI: 10.1080/13691830701265628.

Basualdo V., Esponda M.A., Morales D. (2014). La tercerización en América Latina en las últimas décadas. Visiones, debates y aportes. In: Basualdo V., Morales D., compilation, La tercerización laboral. Orígenes, impacto y claves para su análisis en América Latina. Buenos Aires: Siglo XXI Editores: 65-153.

Benencia R. (2009). El infierno del trabajo esclavo. La contracara de las 'exitosas' economías étnicas. Avá, 15: 43-72.

Browne I., Misra J. (2003). The Intersection of Gender and Race in the Labor Market. Annual Review of Sociology, 29: 487-513. DOI: 10.1146/annurev. soc.29.010202.100016.

Caggiano S. (2014). Desigualdades entrelazadas, luchas divergentes: migración e industria textil en Argentina. Revista CIDOB d'Afers Internacionals, 106-107: 151-170.

Caro E., Berntsen L., Lillie N., Wagner I. (2015). Posted Migration and Segregation in the European Construction Sector. Journal of Ethnic and Migration Studies, 41(10): 1600-1620. DOI: 10.1080/1369183X.2015.1015406.

Castles S. (2013). Migración, trabajo y derechos precarios: perspectiva histórica y actual. Migración y Desarrollo, 11(20): 8-42.

Ceccagno A. (2016). Compressing Diversity: Ethnicization of the Workforce and Outsourcing of Social Reproduction as Assets for the Italian Fashion Industry. Social Science Asia, 2(1): 92-111. DOI: 10.1111/wusa.12121108.

Ceccagno A. (2015). The Mobile Emplacement: Chinese Migrants in Italian Industrial Districts. Journal of Ethnic and Migration Studies, 41(7): 1111-1130, http://dx.doi.org/10.1080/1369183X.2014.967755.

Cerrutti M. (2005). La migración peruana a la Ciudad de Buenos Aires: su evolución y características. Población de Buenos Aires, 2(2): 7-28.

Coutinho B. (2015). Imigração laboral e a produção de vestuário na cidade de São Paulo: entre a informalidade e a expectativa de mobilidade social ascendente. Cadernos OBMigra, 3(1): 79-98.

Cravino M.C. (2008). Relaciones entre el mercado inmobiliario informal y las redes sociales en asentamientos informales del área metropolitana de Buenos Aires. Territorios, 18-19: 129-145.

De Marinis P. (2011). Derivas de la Comunidad: algunas reflexiones preliminares para una teoría sociológica en (y desde) América Latina. SINAIS. Revista Eletrônica - Ciências Sociais, 9(1): 83-117. DOI: 10.25067/s.v1i09.2781. 
Dewey M. (2015). El orden clandestino. Política, fuerza de seguridad y mercados ilegales en Argentina. Buenos Aires: Katz ediciones.

Falcón Aybar M.C., Bologna E. (2013). Migrantes antiguos y recientes: una perspectiva comparada de la migración peruana a Córdoba, Argentina. Migraciones Internacionales, 7(1): 235-266. DOI: 10.17428/rmi.v6i24.715.

Gago V. (2014). La razón neoliberal. Economías barrocas y pragmática popular. Buenos Aires: Tinta Limón Ediciones.

Gallinati C. (2014). Migración, vivienda e integración regional: Un abordaje desde la villa miseria. Buenos Aires: Facultad de Ciencias Sociales, Universidad de Buenos Aires.

Geertz C. (1994). Thick description: Toward an interpretive theory of culture. Readings in the philosophy of social science, $\mathrm{n} / \mathrm{d}$ : 213-231.

Goldberg A. (2013). Un abordaje comparativo en torno a la incidencia de la tuberculosis en inmigrantes bolivianos de Buenos Aires y San Pablo. Revista Interdisciplinar de Mobilidade Humana (REMHU), 21(40): 93-106. DOI: 10.1590/S1980-85852013000100006.

Guber R. (2004). La etnografía. Método, campo y reflexividad. Buenos Aires: Norma.

Gutiérrez Aguilar R. (2008). Los ritmos del Pachakuti. Movilización y levantamiento popular-indígena en Bolivia. Buenos Aires: Tinta Limón.

Hammersley M., Atkinson P. (2007). Ethnography. Principles in practice. London: Routledge.

Harvey D. (1993). The Social Construction of Space and Time: A Relational Theory. Geographical Review of Japan, 67(2): 126-135. DOI: 10.4157/grj1984b.67.126.

Magliano M.J. (2016). Varones peruanos en Argentina y trayectorias laborales en costura. Masculinidades, roles de género y organización del trabajo en contextos migratorios. Universitas Humanística, 81: 331-356. http://dx.doi. org/10.11144/Javeriana.uh81.vpea.

Magliano M.J., Perissinotti M.V., Zenklusen D. (2014). Estrategias en torno a las formas de apropiación y organización del espacio en un 'barrio de migrantes' de la ciudad de Córdoba, Argentina. Revista Estudios Demográficos y Urbanos, 29(3): 513-539.

Mezzadra S. (2012). Capitalismo, migraciones y luchas sociales. La mirada de la autonomía. Nueva Sociedad, 237: 159-177.

Montero Bressán J., Arcos A. (2017). How do Migrant Workers Respond to Labour Abuses in 'Local Sweatshops'? Antipode, 49(2): 437-454.

Piore M. (1979). Birds of Passage: Migrant Labor in Industrial Societies. Cambridge: CUP.

Portes A., Bach R. (1985). Latin Journey. Cuban and Mexican Immigrants in the United States. Berkeley: University of California Pres.

Quiroga Díaz N., Gago V. (2014). Los comunes en femenino. Cuerpo y poder ante la expropiación de las economías para la vida. Economía y Sociedad, 19(45): 1-19. DOI: 10.15359/eys.19-45.1.

Rebord G., Mulatero Bruno D., Ferrero A. (2014). Mercado informal del suelo urbano en Córdoba. Estudios sociales contemporáneos, 11: 63-75. 
Riesco Sanz A. (2003). Enclaves y economías étnicos desde la perspectiva de las relaciones salariales. Cuadernos de Relaciones Laborales, 21(2): 103-125. DOI: $10.5209 /$ CRLA.33527.

Rosas C. (2010). Implicaciones mutuas entre el género y la migración. Mujeres y varones peruanos arribados a Buenos Aires entre 1990 y 2003. Buenos Aires: Eudeba.

Saitta P. (2015). Potere e resistenze.Economie informali, illegalitá, subalternitá. Sociologia e ricerca sociale, 107: 5-26. DOI: 10.3280/SR2015-107001.

Sassen S. (2007). Una sociología de la globalización. Buenos Aires: Katz Ediciones.

Sassen S. (2003). Contrageografías de la globalización. Género y ciudadanía en los circuitos transfronterizos. Madrid: Traficantes de sueños.

Silva S. (1999). Estigma e mobilidade: o imigrante boliviano nas confecções de São Paulo. Revista Brasileira de Estudos de Populacion, 16(1-2): 111-120.

Techo Argentina (2013). Relevamiento de asentamientos informales. Buenos Aires: Techo.

Terrones Ribas A. (2005). Política social y exclusión residencial de las mujeres inmigrantes en Madrid y Barcelona. In: Solé C., Flaquer L., compilation, El uso de las políticas sociales por las mujeres inmigrantes. Madrid: Instituto de la Mujer: 193-298.

Vaccotti L. (2014). Migraciones, espacio y política Perspectivas teóricas para el abordaje del rol del Estado en la 'lucha por la vivienda' (Ciudad de Buenos Aires, 2001-presente). Estudios Sociales Contemporáneos, 11: 38-50.

Wacquant L. (2016). Revisiting territories of relegation. Class, ethnicity and state in the making of advanced marginality. Urban Studies, 53(6): 1077-1088. DOI: $10.1177 / 0042098015613259$.

Wacquant L. (2003). Ethnografeast. A Progress Report on the Practice and Promise of Ethnography. Ethnography, 4: 5-14. DOI: 10.1177/1466138103004001001. 